\title{
C. H. Pander's introduction to conodonts, 1856
}

It is rare in the annals of science for a single publication to provide a definitive introduction to a previously unknown group of animals. Yet this was the case with the monograph that included the initial descriptions of an important, extinct group of fossil animals: the conodonts. The publication, by Christian Heinrich Pander, appeared in St Petersburg in 1856. The volume of ninety-one pages, written in German and accompanied by seven beautifully executed plates, was issued by the Imperial Academy of Sciences as part of a series entitled Geognostische Beschreibung der Russisch-Baltischen Gouvernements.

For the seventy years following 1856, Pander's description of conodonts provided an essentially unmodified account of this newly discovered animal group. Furthermore, with the discovery in 1926 of the potential value of conodonts in stratigraphic correlation, this zoologically enigmatic group of fossils rapidly assumed the position of importance in Paleozoic and Triassic biostratigraphic work that it enjoys today. So, in recognition of Pander's important work, we offer this tribute in honor of the fortieth anniversary of the Pander Society, an international association of micropaleontologists formed in his honor.

Siegfried and Gross (1971) have described Pander's four monographs on Lower Paleozoic fossils as classic, and Raikov (1964), in an assessment of all of Pander's scientific contributions, regards him as the founder of Russian paleontology. He is also commonly seen as one of the founders of the field of embryology. In this contribution we focus on that part of his 1856 monograph in which he named, discussed, and analyzed conodonts.

\section{Biographical Review}

Extensive biographical studies of Pander have been published in German by Erman (1859), Lubosch (1918), Loesch (1920), Siegfried and Gross (1971), and Knorre (1973). Schmitt (2005), which emphasizes Pander's contribution to embryology, is a recent contribution in English. Our review relies heavily on Raikov (1964), which was written originally in Russian but was issued in a German edition in 1984 with accompanying English summaries and commentary by W. E. von Herzenberg and P. H. von Bitter. We extract the following from the latter report.

Christian Heinrich Pander (Figure 1) was born in Riga, Latvia (then Livland or Livonia) on 23 July 1794 , to a prosperous merchant-banker, Johann Martin Pander, and his wife Ursula. He had three brothers and four sisters. Pander's early training in Riga was in a German-speaking gymnasium, from which he graduated in 1812, aged eighteen. Between 1812 and 1817 he took up the study of medicine in Dorpat (now Tartu, Estonia), and subsequently in universities in Berlin, Göttingen, and Würzburg. In 1817 , he received a doctorate in medicine in Würzburg. His dissertation concerned the development of the chick in the egg and is widely regarded as a fundamental contribution to the field of embryology.

Between 1818 and 1820, Pander toured European museums to study animal skeletons in preparation for a planned work with Eduard d'Alton on vertebrate anatomy, and served a brief period in Tartu as editor of a scientific journal. In 1820, Pander became an adjunct in zoology in the Academy of Sciences in St Petersburg, and in that capacity he joined a Russian diplomatic mission to the Emirate of Bukhara in Central Asia. In 1821, the first of fourteen installments of a series titled 'Comparative Osteology' and co-authored with d'Alton was published in Bonn. During this period, Pander's research focused primarily on the comparative anatomy of living and fossil vertebrates. Within one of the publications that resulted from this research, Pander (1824) formulated ideas on 'uninterrupted change or metamorphism' in plants and animals in an essay entitled 'General observation about the outside influences on the organic development of animals'. This contribution was later cited by Charles Darwin as one of the forerunners of his hypothesis that the evolution of living organisms is guided by natural selection.

In 1825, Pander married Amalie von Scherer, with whom he ultimately fathered three sons and four daughters. Shortly after his marriage, while on sick-leave from the Academy, he conducted field studies in southern Russia and, upon return to St Petersburg in 1826, he became a regular member of the Academy. He resigned a year later, however, discouraged by the Academy's rules and practices.

From 1827 to 1833, Pander conducted independent studies in the surrounding area of St Petersburg. In 1830, he published at his own expense, a 165-page report on the geology of the St Petersburg region. This report, accompanied by a geological map and thirty-two hand-colored plates illustrating various fossils, was a pioneering study that established Pander as the leading authority on geology of this segment of the Baltic region, several years before publication of the work of Murchison and Sedgwick. It also earned him recognition (many years later) as the father of paleontology in Russia.

In 1833, Pander was persuaded by his father to return to the family estate, Zarnikau, near Riga, where he and his growing family remained until 1844. During this eleven-year period Pander traveled widely in the Baltic provinces, extending his knowledge of their geology and making additional collections of fossils from the Lower Paleozoic strata exposed there. His fame as the authority on the geology of this region was confirmed by a visit to Zarnikau in 1841 by Murchison, Verneuil, and Keyserling on their way home from their studies in the Urals. During this visit, Pander almost certainly exhibited the microfossils he later named Conodonten, and solicited opinions as to their zoologic affinities.

Pander's father died in 1842, and this greatly altered his son's financial situation. Thus, two years later, in 1844, Pander returned to St Petersburg, where he found employment as a specialist responsible for 'special tasks' in the scientific section of the Department of Mines. This period in Pander's life saw the publication of important reports and papers on a variety of geological and paleontological subjects, including further information on the bedrock formations of the St Petersburg region; the possibility of salt in the vicinity of Novgorod; coal on both slopes of the Urals; and, of course, his four extensive reports on fossil Paleozoic fishes. The first of these monographs, issued in 1856, included the first report of conodonts, the subject of the present paper. Completion of the conodont monograph was especially creditable as Pander suffered from eye problems that inhibited his use of a microscope.

Pander died on 22 September 1865, following an operation for kidney stones. He was buried in the Smolenska Lutheran Cemetery in St Petersburg, but his grave has not been preserved. 


\section{The content of Pander (1856)}

Following an extended six-page introduction, Pander's 1856 monograph, titled Monographie der Fossilen Fische der Silurischen Systems der Russisch-Baltischen Gouvernements, was divided into two major parts. The first, thirty-four pages long, was titled Untersilurische Fische. This section consisted of Pander's detailed interpretation and careful taxonomic treatment of Conodonten. This newly recognized suprageneric taxon was based on Pander's study of thousands of minute fossils he had collected from what would now be regarded as Ordovician and Silurian strata in various parts of the Baltic provinces and from Devonian and Carboniferous rocks as far away as the environs of Moscow. The second and somewhat longer section was forty-one pages long and dealt in detail with extended description and careful taxonomic treatment of a large collection of mostly fragmentary fossil fishes.

The 1856 monograph was accompanied by a full-page text-figure depicting cross-sections of conodont elements and eight large, foldout plates of which the first four (see Figures 2-5) were devoted almost entirely to carefully executed illustrations of the conodont elements described in the first part. In a brief addendum, following page 79, Pander noted the receipt of additional specimens of Silurian fish from a colleague in Tartu and proposes a new name, Lonchodus, for the conodont genus Centrodus that he established formally on Page 31.

Conodonts, the subjects of the first part of Pander's 1856 monograph, were considered to be the teeth of an extinct group of fishes. This group was diagnosed (in German) in terms of its fossil remains as (our translation):

Tiny, lustrous, elongated remains very similar in shape to fish teeth, [which] extend upward or toward one end into a point; [which] widen gradually or abruptly downward; [which are] more or less curved, and most [of which] have sharp margins (keels), one in front and one in back.

Pander continued to note that the fossils were of very different shapes; some symmetrical, some not, and were provided with faces that were smooth or longitudinally striated, and commonly had a sharp carina that projected laterally from the smooth surface. Clearly, Pander based his diagnosis on what he termed simple teeth; and in a later paragraph, he noted that compound teeth consisted of a central tooth with rows of smaller teeth located on an expanded base.

Conodont specimens were divided by Pander into crown (Spitze) and base (Basis). The crown was solid, the base hollow. In line with his interpretation of these fossils as fish teeth, the hollow base was interpreted as the site of the pulp cavity (cavitas pulpae). Bases (and their included pulp cavities) were shown to have various shapes, all of which were illustrated on the plates accompanying the monograph.

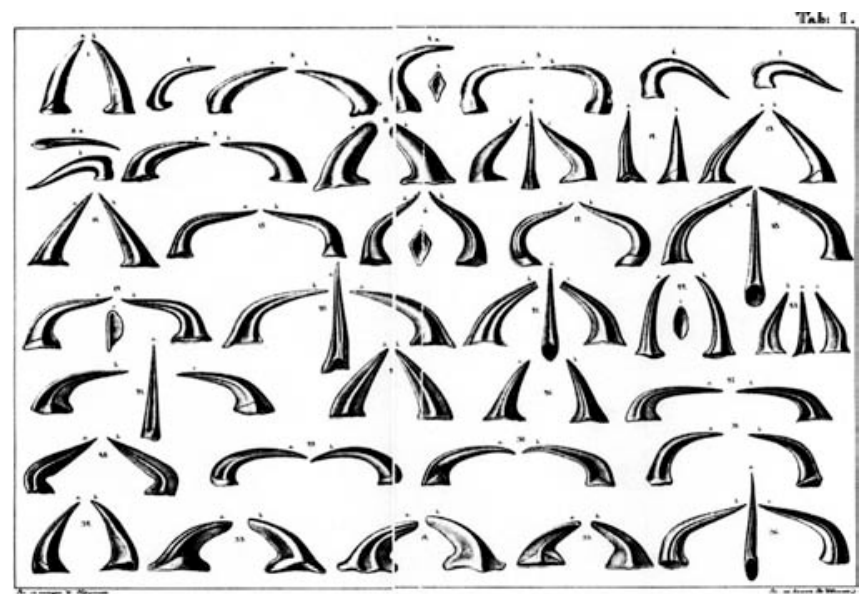

Figure 2 Plate 1 from Pander (1856) illustrating a variety of the conodont elements that Pander termed 'simple teeth'.

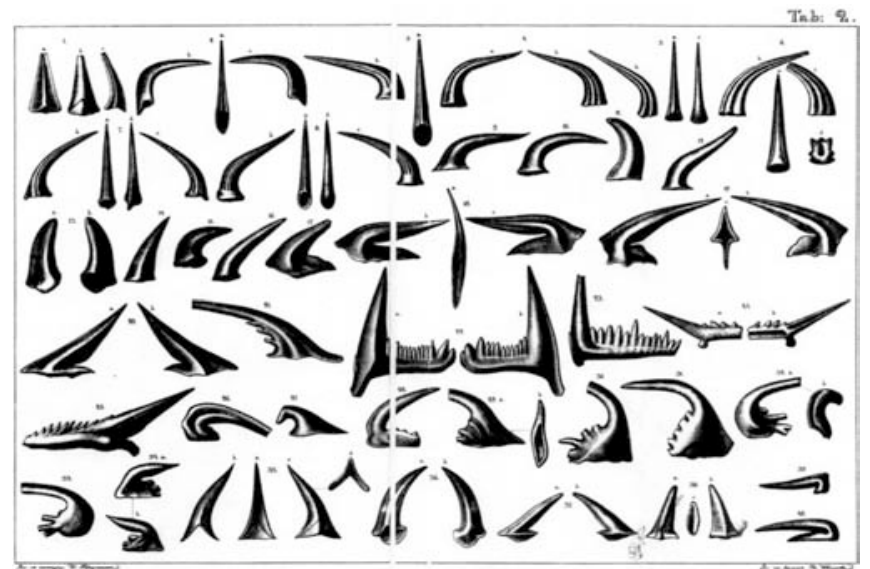

Figure 3 Plate 2 from Pander (1856) illustrating both 'simple' and 'compound' teeth. Original is a large fold out measuring about $23-35 \mathrm{~cm}$.

Pander wrote that it was noteworthy that the conodont specimens in his large collection all seemed to be largely unaltered and retained their original color and luster. They appeared to be composed of pure calcium carbonate (Reinem kohlensauren Kalk) and, because of their unaltered condition, Pander reported that it was possible to study their internal structures, of which he recognized (and illustrated) three types. One type was snow-white and not transparent but with translucent margins; a second type was yellow and completely translucent; a third was reddish white, compact and completely opaque. Pander concluded that the completely translucent specimens without white matter represented youthful stages of growth, whereas those with white matter represented later growth stages. He was evidently puzzled about the significance of the mostly compound specimens that exhibited the third type of structure.

Pander then turned to the structure of 'these teeth', which he noted apparently differed in icthyological character from all previously known fish. This had initially given rise to the impression that the fossil remains were not fish teeth. However, after a careful study of the internal structure of several translucent simple specimens, two of which had been sectioned longitudinally, Pander concluded that the cone-shaped lamellae conformed to the shape of the pulp cavity and had been added by internal apposition, so that the outer surface was the oldest. He recognized and illustrated other internal features, but was unable to see anything that he could identify as bone.

Indeed in his large collections of conodont elements Pander found no bone or anything else that he could identify as other parts of a conodont skeleton. Thus, he concluded that it was highly unlikely that conodonts had any other hard parts. He suggested that this was also the case with the teeth of such animals as hagfish and lampreys, and that these living organisms might somehow be related.

Finally, after a careful comparison of specimens in his large collection, Pander confessed (on page 18) that we do not know what types of teeth we have before us, whether they belong to the jaws, the gums, the lips, or the tongue, nor whether each particular shape serves as the basis for establishment of its own genus and species, or whether different forms might have come from the same body.

Unable to solve this puzzle, Pander chose in the following pages of his monograph, to use a strict, almost mechanical form taxonomy for the formal description of the specimens in his collection. That is, each species of conodont was interpreted to have had teeth of a single morphology. Thus, the systematic portion of the section of his monograph included the establishment of fifty-five newly named species in thirteen genera, all taxa being based on the shapes of typical specimens. Typical representatives of each species are illustrated on the four conodont plates (see Figures 2-5). 


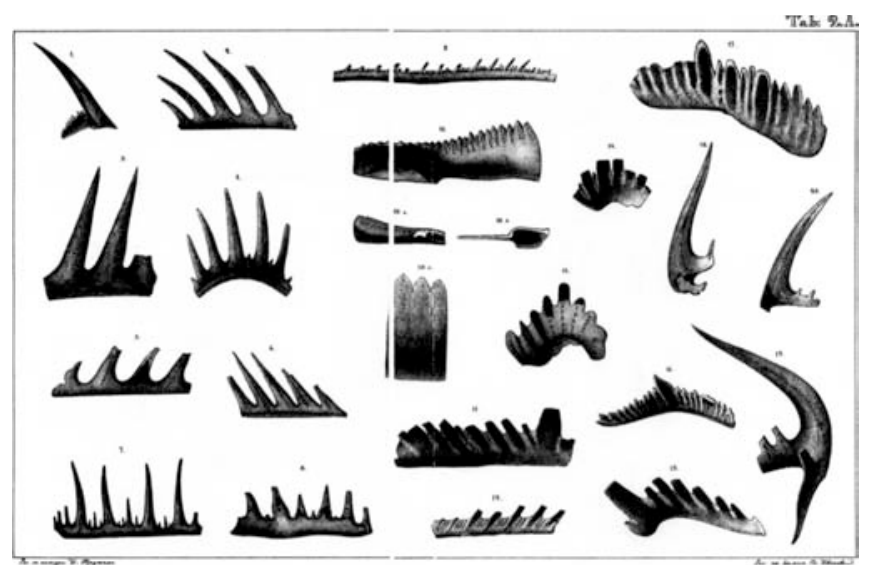

Figure 4 Plate 2A from Pander (1856) illustrating conodont elements of the type that Pander termed 'compound' teeth. The original is a large fold out measuring about $23-35 \mathrm{~cm}$.

\section{The next 150 years}

For some seventy years after the publication of Pander's 1856 monograph, conodonts seem to have been regarded largely as paleontological curiosities, and there was continued speculation as to their zoological affinities. One contribution in this period stands out however. This was a paper by G. J. Hinde (1879) in which he not only described a number of Ordovician and Devonian conodont specimens that he had collected in North America, but also reviewed Pander's monograph. He noted the lamellar internal structure of conodont elements that Pander had described but found specimens in which the basal body appeared to lack such a structure. Such bodies, later termed basal fillings, were not preserved in the specimens in Pander's collection and are also absent in the majority of specimens in other collections. Hinde agreed with Pander's description of the white structure of some specimens, but interpreted it to be the result of weathering, not the internal dissolution in late growth stages. In addition he concluded that a number of differently-shaped specimens found clustered together on a black shale slab represented a single individual. These he named Polygnathus dubius. Hinde also reported that he had shown his specimens to Huxley, who agreed with Pander that myxinoid fishes were probably the conodonts' closest relatives. And, finally, Hinde's collections included laterally expanded, plate-like specimens of a type not described by Pander. These were termed pectinate specimens.

The next major publication dealing with conodonts, a lengthy bulletin by E. O. Ulrich and R. S. Bassler, appeared in 1926 and was based on U. S. National Museum collections from Devonian and Mississippian rocks in the southeastern United States. In the introduction to this bulletin, the authors noted their agreement with Pander that myxinoid fishes were probably the closest relatives of some conodonts, but suggested that sharks and other fish groups might also have been involved. They emphatically disagreed with Hinde that some conodonts might have had 'teeth' of several different shapes, and based their comprehensive classification of the conodonts on a rigorous form taxonomy, which they admitted might be somewhat artificial. The principal contribution of the Ulrich-Bassler study was its demonstration of the fact that conodonts might be used successfully in the biostratigraphic correlation of strata.

As they predicted, the study by Ulrich and Bassler sparked an interest in the biostratigraphic use of conodonts in the United States. For example, in 1926, Roundy described collections from Mississippian rocks in Texas; Stauffer (1930) illustrated material from the Middle Ordovician; Gunnell (1931) described conodonts from the Fort Scott Limestone of Missouri; and Stauffer and Plummer (1932) reported on collections from the Pennsylvanian of Texas. In 1933, E. B. Branson and M. G. Mehl of the University of Missouri published a series of reports collectively titled 'Conodont Studies', which documented the occurrence of conodonts from the middle of the Ordovician through the lower part of the Carboniferous (Mississippian) of eastern and central United States. Furnish (1938) added a study of Lower Ordovician faunas, and, by mid-twentieth century, the known stratigraphic range of conodonts was from late Cambrian to latest Triassic. During this period Pander's name continued to be remembered by researchers in the proposal of new conodont taxa, for example in the genera Panderodella, Panderodus, Panderolepis, Pandorina, and Pandorinellina.

Biostratigraphers, enthused by the correlation potential of conodonts, spent little time on studying the composition and structure of conodont specimens. But ultimately it was determined that specimens are composed largely of francolite, a carbonate apatite, and include traces of at least thirty-nine other elements. Furthermore, laminae in element crowns include, or are separated by, thin films of un-mineralized tissue that darken gradually as elements are heated and more of the carbon in this organic material becomes fixed. Also, it has been demonstrated that conodont elements grew by external apposition so that the outer surface of these specimens is the youngest, not the oldest as Pander concluded.

The discovery of additional clusters of elements in the 1930s and 1950s and, in the 1960s, the determination that groups of differently shaped elements formed recurrent associations, paved the way to the development of a multi-element taxonomy, which Pander had considered a possibility back in 1856, and which is now the generally accepted basis for understanding and describing conodont species.

In 1856, Pander noted that simple conodont specimens dominated his Lower Ordovician collections but that collections from younger rocks were composed mostly, or entirely, of compound forms. This observation has been repeatedly confirmed by post-1856 studies and is, in essence, the basis for recognizing biostratigraphically useful successions of conodont species.

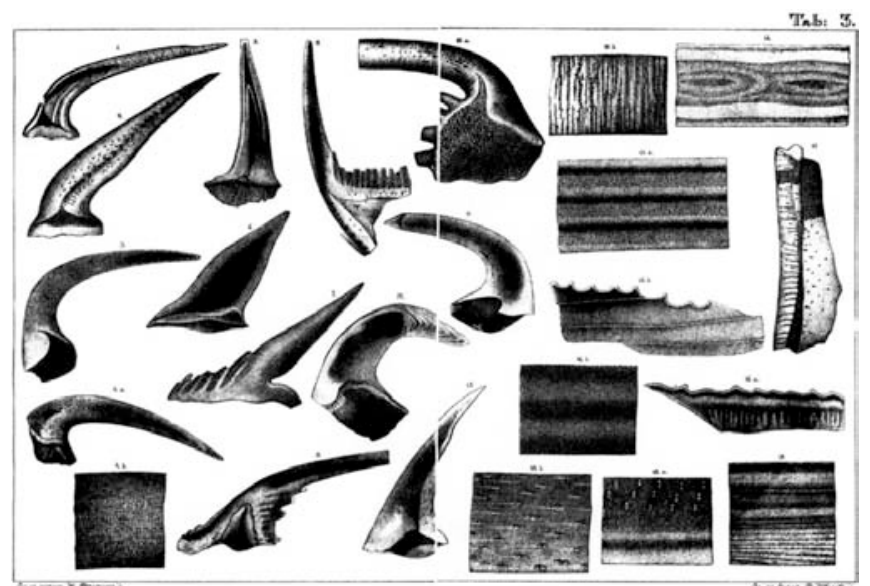

Figure 5 Plate 3 from Pander (1856). Specimens on the left are 'simple' and 'compound' conodont elements, several showing internal laminated structures. Specimens on the right side are not conodonts, but sections of brachiopod shells and one ostracode. The original is a large fold out measuring about $23-35 \mathrm{~cm}$.

The especially important discovery, in 1983, of several Scottish specimens that represent more or less complete conodonts, and the careful study and description of these specimens by Aldridge $e t$ al . (1986), seems to have confirmed Pander's suspicion that the discrete specimens in his collection were the only parts capable of preservation in a group of animals related to myxinoid or lamprey-like fishes. The position of conodonts as extinct chordates, more 'derived' than living jawless vertebrates, but less so than those with jaws, has been established by cladistic analysis and has been summarized recently by Sweet and Donoghue (2001).

Finally, we should mention that the widespread occurrence of well-preserved conodont elements, representing distinctive evolutionary sequences, has attracted hundreds of students to the study of conodonts and, through the establishment of the Pander Society in 
1967 has promoted widespread exchange of ideas about this once ubiquitous group of marine animals. The Society is an informal association that presently has 184 members in some thirty-three countries. It has published and distributed a newsletter annually since the year of its founding, and on occasions it awards a gold medal to a member for outstanding contributions to the study of conodonts. Pander would surely be pleased to read the many reports of the last forty years that have demonstrated the credibility of a multi-element taxonomy based on the geographic and stratigraphic co-occurrence of groups of differently shaped elements, rather than on the rigorously mechanical taxonomy based on the shape of individual elements that he reluctantly accepted in 1856 . Pander would be even more delighted, we believe, in studies that confirm his conclusion that conodonts may reliably be classified as an independent group of primitive vertebrates.

\section{References}

Aldridge, R. J., Briggs, D. E. G., Clarkson, E. N. and Smith, M. P., 1986, The affinities of conodonts-new evidence from the Carboniferous of Edinburgh, Scotland: Lethaia, v. 19, pp. 1-14.

Branson, E. B. and Mehl, M. G., 1933, Conodont studies: University of Missouri Studies, v. 8, Nos 1-4.

Erman, A., 1859, Über Herrn Dr. C. H. Panders paläographische und geologische Arbeiten: Archiv für wissenschaftliche Kunde von Russland, v. 18, pp. 384-445. Berlin.

Furnish, W. M., 1938, Conodonts from the Prairie du Chien (Lower Ordovician) beds of the Upper Mississippi Valley: Journal of Paleontology, v. 12 , pp. 318-340.

Gunnell, F. H., 1931, Conodonts from the Fort Scott Limestone of Missouri: Journal of Paleontology, v. 5, pp. 244-252.

Hinde, G. J., 1879, On conodonts from the Chazy and Cincinnati Group of the Cambro-Silurian, and from the Hamilton and Genesee shale divisions of the Devonian in Canada and the United States: Quarterly Journal of the Geological Society of London, v. 35, pp. 351-369.

Knorre, H. v., 1973, Briefe von Christian Heinrich Pander (1794-1865) an Ernst von Baer (1792-1876): Giessener Abhandlungen zur Agrar.-und Wirtschaftsforschung des Europäischen Ostens, v. 59, pp. 89-116.

Loesch, E., 1920, Heinrich Christian Pander, seine Leben und seine Werke: Biologisches Zentralblatt, v. 40, pp. 481-502.

Lubosch, W., 1918, Über Pander und Altons vergleichende Osteologie der Saugetiere: Flora (New Series), vols 11/12 (Festschrift Stahl), pp. 668-702. Jena

Pander, C. H., 1824, Die Skelete der Nagethiere, zweite Abh., abgebildet und verglichen von Dr. Chr. Pander und Dr. E. d'Alton. Mit 8 Kupfern. (5 Lieferung): Bonn: Weber. [Bonn, den 26 Nov. 1823].
Pander, C. H., 1830, Beiträge zur Geognosie des russischen Reiches (Subtitle, Die Umgebungen von St. Petersburg). 165 pp. Kray, St. Petersburg (also Kayser Bucher-Lexicon, Leipzig).

Pander, C. H., 1856, Monographie der fossilen Fische des silurischen Systems der russisch-baltischen Gouvernements. St Petersburg: Buchdruckerei der Kaiserlichen Akademie der Wissenschaften, 91 pp., 9 plates

Raikov, B. E., 1964, Christian Heinrich Pander, ein bedeutender Biologe und Evolutionist, 1794-1865. German Translation with Commentary and English Summaries by Hertzenberg, W. E. von and Bitter, P. H. von, 1984: Senckenberg-Buch, v. 62, 144 pp.

Roundy, P. V., 1926, The microfauna of Mississippian formations of San Saba County, Texas: United States Geological Survey, Professional Paper No. 146, pp. 5-17.

Schmitt, S., 2005, From eggs to fossils: epigenesis and transformation of species in Pander's biology: International Journal of Developmental Biology, v. 49, pp. 1-8.

Siegfried, P. and Gross, W., 1971, Christian Heinrich Pander 1794-1865 und seine Bedeutung für die Paläontologie: Münstersche Forschungen zur Geologie und Paläontologie, v. 19, pp. 103-183, 4 figures \& 6 plates.

Stauffer, C. R., 1930, Conodonts from the Decorah shale: Journal of Paleontology, v. 4, pp. 121-128.

Stauffer, C. R. and Plummer, H. J, 1932, Texas Pennsylvanian conodonts and their stratigraphic relations: University of Texas, Bulletin No. 3201, pp. 14-22.

Sweet, W. C. and Donoghue, P. C. J., 2001, Conodonts: past, present, future: Journal of Paleontology, v. 75, pp. 1174-1184.

Ulrich, E. O. and Bassler, R. S., 1926, A classification of the toothlike fossils, conodonts, with descriptions of American Devonian and Mississippian species: Proceedings of the United States National Museum, v. 68, pp. $1-63$.

Walter C. Sweet

School of Earth Sciences

The Ohio State University

Columbus, $\mathrm{OH} 43210$

USA

Barry J. Cooper

Primary Industries and Resources South Australia GPO Box 1671

Adelaide SA 5001

AUSTRALIA 